\title{
Comparing growth models for inter annual progress of yellow rust (Pucinia striiformis) in wheat (Triticum aestivum) in relation to weather
}

\author{
RAJENDER SINGH*, RAM NIWAS ${ }^{1}$ and S.S.KARWASRA \\ Department of Plant Pathology, ' Department of Agro-meteorology \\ CCS Haryana Agricultural University, Hisar-125004, Haryana, \\ *e-mail:rsb1965@gmail.com
}

\begin{abstract}

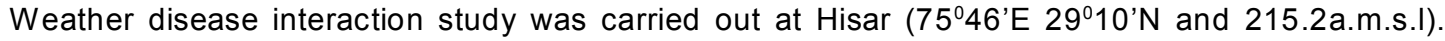
Nineteen years (1996-2014) yellow rust data was recorded during the peak period of yellow rust incidence $\left(20^{\text {th }}\right.$ December to $20^{\text {th }}$ February) on six varieties of wheat $(\mathrm{WH} 147, \mathrm{PBW} 343, \mathrm{WH} 711$, PBW 175 , KH 65 and C 306). Weather data of corresponding period (1996 to 2014) was taken from Agrometeorological observatory located at Research farm. Yellow rust incidence values were transformed using Logistic and Gompertz models for development of weather based prediction models. Transformed values of disease incidence were correlated with weather parameters and correlation coefficient indicates that rainy day was the most important/significant weather parameters in disease progression. Rainy day, minimum temperature and morning relative humidity collectively explained maximum variability in disease progression. The Gompertz model was found to be the best fit over the years for describing zonate leaf spot disease incidence in a natural inoculum population of Pucinia striiformis on wheat
\end{abstract}

Key words: Yellow rust, weather, Gompertz model, Logistic model, regression model

Stripe (yellow) rust, incited by Puccinia strifformis Westend f. sp. tritici Eriks.. (Pst), is one of the most widely destructive wheat diseases in modern cereal production (Wellings, 2011). Stripe rust appears as a mass of yellow to orange urediniospores erupting from pustules arranged in long, narrow stripes on leaves (usually between veins), leaf sheaths, glumes and awns on susceptible plants. Resistant wheat cultivars are characterized by various infection types from no visual symptoms to small hypersensitive flecks to uredinia surrounded by chlorosis or necrosis with restricted urediniospore production. Stripe rust is considered to be a low-temperature disease and frequently occurs in temperate areas with cool and moist weather conditions. Urediniospores are primarily responsible for wide-scale stripe rust epidemics reported on cereal crops. The most important weather factors are temperature, moisture, and light and air pollution. Temperature is critical for successful germination and infection. Urediniospores can germinate rapidly when free moisture (rain or dew) occurs on leaf surfaces and when the temperatures range is between 7 and $12{ }^{\circ} \mathrm{C}$. At higher temperatures or during the later growing stages of the host, black telia are often produced Pst is capable of long-distance dispersal by wind movement and human-assisted transport (Brown and Hovmøller, 2002). Resistance breeding against fungal diseases in wheat crop can have some solution against disease incidence (Bockus et al., 2001). However, the wheat varieties are not resistant to all important fungal diseases. Resistant varieties also lose resistance with time and may become susceptible to diseases on evolution of new races. The impact of disease incidence can be reduced by cultural practices, but not fully under favorable weather conditions

Many fungal diseases in wheat are effectively controlled by seed treatments and spray with fungicide in time. Use of fungicide needs to take into the consideration for crop protection requirements of the grower and environmental problems. Both can be achieved with justified/judicious use of fungicide in unjustified case. It has caused yield losses up to 62.94 per cent in experimental plots and up to $61.84 \%$ in farmer's fields in variety PBW 343 during 2008-09 throughout the Punjab (Pannu et.al. 2010). In Australia, the most important pathogen was Puccinia striiformis with current average annual loss of $\$ 127 \times$ $10^{6}$ (Murray and Brennan. 2009). Chen (2005) reported, 1070 per cent yield losses due to stripe rust in wheat producing areas of world depending upon the susceptibility of cultivar, earliness of initial infection, rate of disease development and duration of disease. Yellow rust, will increase 5-20\% in the cold areas (Simone et.al.2013). 
Disease incidence prediction may help in whether fungicide should be applied or not (Milne et al., 2007). Weather is the driver of the disease development. Weather factors are essential in prediction of disease incidence including different phases of disease cycle. The disease incidence in relation to weather has been the subject of many studies, but further studied is required to evaluate the relationships carefully for use in weather based agro advisories. Prediction accuracy will be improved by fitting Logistic and Gompertz models transformations for developing linear regression weather based models Hence, the present study is planned to compare the Logistic and Gompertz models for disease transformations to develop the best fit weather based linear regression models for yellow rust prediction accounting maximum variability in wheat.

\section{MATERIALS AND METHODS}

Weather-yellow rust interaction study was carried out at the Research farm of the Chaudhary Charan Singh,

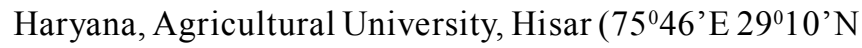
and 215.2 a.m.s.1). Weather data of 1996 to 2014 was taken from Agrometeorological observatory located at Research farm of the university. Weather data were averaged for the growth period of wheatfrom 20 December to 20 February, in each year, as it mainly occurred during this period. The data of rainfall and rainy days were cumulated during this period. Yellow rust incidence was recorded on six wheat varieties: WH 147, PBW 343, C 306, WH 711, PBW 175(susceptible) and KH 65 (moderately resistant) from December 20 to February 20 using scale (Peterson et al. 1948) for estimating rust intensity during 1996 to 2014 planted at Plant Pahtology Research farm. The percent disease incidence observed during the period was converted to fraction of one and transformed using the Logistic and Gompertz models as given in Table 1.

The tranformed values of disease incidence were corrleated with the averaged weather data (1996-2014). The transformed disease data was regressed with the significant weather data based on significance of ' $r$ ' valung stepwise regression technique for developing regression models. The predicted values by the best fit models were back transformed. After linear regression, goodness-of-fit (Campbell and Madden 1990, Madden et al. 2008) of the model was determined by examining the co-efficient of determination, root mean square error and the graph of the standardized residuals and the predicted values.

\section{RESULTS AND DISCUSSION}

\section{Weather and disease}

The weather parameters were averaged for the growing period (Dec. 20 to Feb. 20) in each growing season from 1996 to 2014. Range and mean values of data during this period are presented in Table 2. Yellow rust incidence was low in some varieties i.e. KH 65 and in some years. But in some years the disease incidence was very high. Yellow rust incidence was positively correlated with minimum temperature, morning relative humidity, wind spee, rainfall and rainy rays. However, the correlation co-efficient was significant with minimum temperature morning relative humidity, rainfall and rainy days. These weather parameters played significant role in incidence of yellow rust in PBW-175 and KH 65, whereas in case of other wheat varieties it was not significant (Table 3). Maximum temperature, evening relative humidity and bright sun shine hours played a negative role in yellow rust incidence, though it was not significant. Increase in minimum temperaturefavored probably sporulation and infection on young leaves. Daamen, et al. (1992) confirmed these results.

\section{Logistic model}

The transformed values of yellow rust incidence in susceptible variety(PBW 175) by logistic model were regressed with weather parameters of the period 1996-2012 and required equations are presented in Table 4. Simple regression equation based on most significant parameter i.e. rainy day explained the variability in disease incidence up to 60 per cent. However the $\mathrm{R}^{2}$ values were highly significant $(\mathrm{p} \leq 0.00025)$ in case of prediction model developed using transformed disease values for variety PBW 175. Relative humidity and rainy days collectively explained the variability in disease incidence from 62 per cent. Minimum temperature, relative humidity and rainy days collectively explained the variability in disease incidence further improved 10 per cent. The co-efficient of determination of variability was highly significant ( $\mathrm{p} \leq$ 0.005 ) in PBW 175. The regression co-efficient was also significant in case of rainy days among the weather parameters used for the model development. Ewaldz and Wilk (2009) reported that temperature explained more than 50 per cent variation in brown rust and yellow rust incidence in winter wheat.

\section{Gompertz model}

Gompit values of disease incidence showed higher 
Table 1 : Logistic and Gompertz models used in study.

\begin{tabular}{llll}
\hline Model & Equation & Transformation & Anit-transformation \\
\hline Logistic & $\left.\mathrm{Y}=\mathrm{k} /\left(1+\exp ^{-\mathrm{rt}}\right) \mathrm{b}=\left[\mathrm{y}_{\max } / \mathrm{y}_{\mathrm{o}}\right)-1\right]$ & Logit $(\mathrm{y})=\operatorname{In}(\mathrm{y} / 1-\mathrm{y})$ & $\mathrm{y}=[\exp (\operatorname{logist}(\mathrm{y})) /(1+\exp (\operatorname{logit}(\mathrm{y}))]$ \\
Gompertz & $\mathrm{Y}-\mathrm{k} \exp \left(-\mathrm{B} \exp ^{-\mathrm{rt}}\right)$ & Gompit $(\mathrm{y})=-\operatorname{In}(-\operatorname{In}(\mathrm{y}))$ & $\mathrm{y}=[\exp (-\exp (-\operatorname{gompit}(\mathrm{y}))]$ \\
& $\mathrm{B}=-\operatorname{In}(\mathrm{yo}) ; \operatorname{ext}^{-\mathrm{rt}=1, \text { if } \mathrm{t}=0 ;}$ & & \\
& $\mathrm{B}=-\operatorname{In}\left(\mathrm{y}_{\mathrm{t}}\right) / \exp (-\mathrm{rt})$, if $\mathrm{t}<0$ & & \\
\hline
\end{tabular}

$\mathrm{y}=0$ to $1, \mathrm{k}=$ carrying capacity, $\mathrm{t}=$ time (days),

Table 2: Extreme (maximum and minimum) and average values of weather parameters during the period (December 20 to January 20) from 1996-2014

\begin{tabular}{lrrr}
\hline Weather parameters & Maximum & Minimum & Average ISD \\
\hline $\mathrm{T}_{\max }\left({ }^{\circ} \mathrm{C}\right)$ & 22.7 & 17.9 & $19.8 \pm 1.35$ \\
$\mathrm{~T}_{\min }\left({ }^{\circ} \mathrm{C}\right)$ & 7.7 & 2.7 & $5.2 \pm 1.38$ \\
$\mathrm{RH}_{\mathrm{m}}(\%)$ & 97 & 90 & $94 \pm 2.19$ \\
$\mathrm{RH}_{\mathrm{e}}(\%)$ & 70 & 37 & $56 \pm 10.01$ \\
$\mathrm{WS}(\mathrm{Km} / \mathrm{h})$ & 4.4 & 2.7 & $3.6 \pm 0.50$ \\
$\mathrm{BRI}(\mathrm{h})$ & 7.3 & 4.1 & $5.6 \pm 0.84$ \\
$\mathrm{RN}(\mathrm{mm})$ & 80.7 & 0.0 & $30.2 \pm 24.80$ \\
$\mathrm{RD}$ & 6.0 & 0.0 & $2.7 \pm 1.86$ \\
\hline
\end{tabular}

$\mathrm{T}_{\max } \& \mathrm{~T}_{\min }=$ Maximum \& minimum temperature $\left(0^{\circ} \mathrm{C}\right) ; \mathrm{RH}_{\mathrm{m} \&} \mathrm{RH}_{\mathrm{e}}=$ Morning \& evening relative humidity $(\%)$; WS $=$ Wind speed $(\mathrm{kmph}) ; \mathrm{BRI}=$ Bright sun shine $(\mathrm{h}) ; \mathrm{RN}=$ Rainfall $(\mathrm{mm})$ and $\mathrm{RD}=$ Rainy days

Table 3: Correlation matrix among weather parameters and disease incidence (Logit and Gompit values) in wheat cultivars.

\begin{tabular}{lcccccc}
\hline Weather parameters & $\mathrm{V}_{1}$ & $\mathrm{~V}_{2}$ & $\mathrm{~V}_{3}$ & $\mathrm{~V}_{4}$ & $\mathrm{~V}_{5}$ & $\mathrm{~V}_{6}$ \\
\hline $\mathrm{T}_{\text {max }}$ & -.02 & -0.04 & -0.01 & -0.45 & -0.18 & -0.08 \\
$\mathrm{~T}_{\text {min }}$ & 0.22 & 0.14 & 0.16 & $0.52^{*}$ & 0.45 & 0.13 \\
$\mathrm{RH}_{\mathrm{m}}$ & 0.10 & 0.12 & 0.27 & $0.46^{*}$ & $0.46^{*}$ & 0.19 \\
$\mathrm{RH}_{\mathrm{e}}$ & -0.14 & -0.30 & -0.10 & -0.39 & -0.11 & -0.19 \\
$\mathrm{WS}$ & 0.31 & .05 & 0.15 & 0.32 & 0.22 & 0.18 \\
$\mathrm{BRI}$ & -0.15 & -0.16 & -0.21 & -0.34 & -0.22 & -0.12 \\
$\mathrm{RN}$ & 0.14 & .30 & .13 & $0.46^{*}$ & 0.42 & 0.17 \\
$\mathrm{RD}$ & 0.87 & 0.43 & .35 & $0.74^{*}$ & $0.70^{*}$ & 0.33 \\
\hline & & & $\mathrm{G}$ & & \\
\hline $\mathrm{T}_{\max }$ & -0.05 & -0.01 & -0.02 & -0.40 & -0.06 & -0.18 \\
$\mathrm{~T}_{\min }$ & 0.16 & 0.07 & 0.17 & $0.58^{*}$ & 0.23 & 0.01 \\
$\mathrm{RH}$ & 0.15 & 0.17 & 0.15 & $0.49^{*}$ & $0.47^{*}$ & 0.01 \\
$\mathrm{RH}$ & -0.11 & 0.32 & -0.17 & 0.32 & -0.05 & -0.27 \\
$\mathrm{WS}$ & 0.27 & 0.13 & 0.13 & 0.29 & 0.26 & 0.19 \\
$\mathrm{BRI}$ & -0.10 & -0.16 & -0.21 & -0.38 & -0.12 & -0.09 \\
$\mathrm{RN}$ & 0.13 & 0.33 & 0.07 & 0.50 & 0.43 & 0.16 \\
$\mathrm{RD}$ & $0.49^{*}$ & $0.47^{*}$ & 0.43 & $0.79^{*}$ & $0.76^{*}$ & 0.39 \\
\hline $\mathrm{Critic}$ & & & &
\end{tabular}

Critical value of ' $r$ ' of $\mathrm{p} \leq 0.05=0.456,{ }^{*}$ significant at $\mathrm{p} \leq 0.05$

$\mathrm{V}_{1}=\mathrm{WH} 147, \mathrm{~V}_{2}=\mathrm{PBW} 343, \mathrm{~V}_{3}=\mathrm{WH} 711, \mathrm{~V}_{4}=\mathrm{PBW} 175, \mathrm{~V}_{5}=\mathrm{KH} 65, \mathrm{~V}_{6}=\mathrm{C} 306$ 
Table 4 : Regression models for estimation of disease incidence transformed values with weather parameters in wheat (1996

\begin{tabular}{|c|c|c|c|}
\hline Variety & Models with Logit values & $\mathrm{R}^{2}$ & $\mathrm{p}$ \\
\hline \multirow[t]{3}{*}{ PBW 175} & $\begin{aligned} & \mathrm{Ly}=-5.319+ \\
&(4.736)^{*}\end{aligned}$ & 0.60 & 0.00025 \\
\hline & $\begin{array}{r}\mathrm{Ly}=-15.601+0.111 \mathrm{RH}_{\mathrm{m}}+0.686 \mathrm{RD} \\
(0.771)\end{array}$ & 0.62 & 0.0015 \\
\hline & 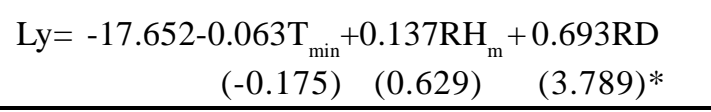 & 0.72 & 0.0055 \\
\hline \multicolumn{4}{|c|}{ Models with Gompit values } \\
\hline \multirow[t]{3}{*}{ PBW 175} & $\begin{array}{r}\mathrm{Gy}=-1.844+0.285 \mathrm{RD} \\
(4.754)^{*}\end{array}$ & 0.62 & 0.00024 \\
\hline & $\begin{array}{r}\mathrm{Gy}=-3.837+0.0215 \mathrm{RH}_{\mathrm{m}}+0.275 \mathrm{RD} \\
(0.353) \quad(4.083)^{*}\end{array}$ & 0.65 & 0.0013 \\
\hline & 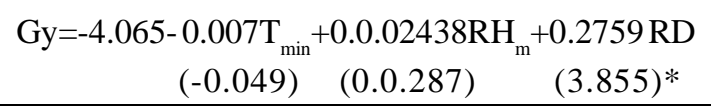 & 0.75 & 0.005 \\
\hline
\end{tabular}

$\mathrm{Y}$ is transformed value of disease incidence :Figure in parenthesis are ' $\mathrm{t}$ ' values

* Significant at $\mathrm{p} \leq 0.05$

Table 5 : Predicted and observed values during 2013 and 2014.

\begin{tabular}{lllll}
\hline $\begin{array}{l}\text { Disease growth } \\
\text { models }\end{array}$ & Year & $\begin{array}{l}\text { Predicted values } \\
\text { Transformed }\end{array}$ & Antitransformed & $\begin{array}{l}\text { Observed values } \\
\text { Incidence in fraction }\end{array}$ \\
\hline Logestic & 2013 & -3.31 & 0.04 & 0.05 \\
& 2014 & -1.71 & 0.15 & 0.10 \\
Gompertz & 2013 & -1.19 & 0.04 & 0.05 \\
& 2014 & -0.81 & 0.11 & 0.10 \\
\hline
\end{tabular}

correlation with weather parameters (Table 3). However the disease response to weather parameters was similar as in case of logit values. Simple model developed for gompit values of disease incidence with rainy days explained the variability up to 62 per cent. However the co-efficient of determination for variability in disease incidence was significant at $p \leq 0.000249$. Relative humidity and rainy days collectively improved the predictability of regression models for yellow rust incidence by 3 per cent (Table 4). The co-efficient of determination for variability in disease incidence prediction by the multiple regression models was enhanced up to 75 per cent. The best fit models were developed for wheat variety, PBW 175. This was because of less resistance of this variety to yellow rust. Kumar et.al (2004) developed the regression models for prediction of downy mildew of pearl millet using transformed values by Logistic and Gompertz models with weather parameters.

Logestic and Gompertz transformation models with weather parameters minimum temperature, relative humidity morning and rainy day (2013 and 2014) were used for prediction of disease (Table 5).

The Gompertz model was found better over logestic for predicting yellow rust incidence in a natural inoculum population of Pucinia striiformis on wheat. This might be because Gompertz model predicts asymmetric disease curve and most of the disease progression is asymmetrical whereas Logistic model curve is symmetrical. Singh et. al (2010 )reported that Gompertz model was best fit over the years for describing zonate leaf spot disease progression in a natural inoculum population of G. sorghi on sorghum (Sorghum bicolor L.).

\section{CONCLUSION}

Based on the above results it is concluded that rainy day is the most significant among weather parameters for yellow rust disease incidence. Rainy day, minimum temperature and morning relative humidity collectively explained the maximum variability in yellow rust incidence. 
The Gompertz model was found to be best fit for describing yellow rust incidence in a natural inoculum population of Pucinia striiformis on wheat.

\section{RFERENCES}

Bockus, W.W., Appel, J.A., Bowden, R.L., Fritz, A.K., Gill, B.S., Martin, T.J., Sears, R., Selfiers, D.L., Brown-Guedira, G.L., Eversmeyer, M.G. (2001).Success stories: breeding for wheat disease resistance in Kansas. Plant Dis. 85; 453-461.

Brown, J.K.M. and Hovmøller, M. (2002). Aerial dispersal of pathogens on the global and continental scales and its impact on plant disease. Science. 297. 537-541.

Campbell C.L and Madden L.V. 1990. Introduction to Plant Disease Epidemiology, 532 pp, John Wiley, New York.

Chen X.M. (2005). Epidemilogy and control of stripe rust (Puccinia striiformis f.sp. tritici) on Wheat. Canadian J. Plant Pathol. 27 :314-37.

Daamen, R.A. and Stol, W. (1992). Survey of cereal disease and pests in Neatherlands.4.Occurence of powdery mildew and rusts in winter wheat. Neth. J. Plant Path., 98:301312.

Ewaldz, T. and Wilk, L. (2009).Impact of temperature and precipitation on yield and plant diseases of winter in southern Sweden 1983-2007.Crop Prot., 28:952-962.

KumarA., Niwas, R., KumarA. andPanwar M.S.(2004). Influence of weather parameters on downy mildew progression in Pearlmilletvar4042-s. HaryanaAgric.Univ.J.Res.34:143147.
Madden L.V., Hughes G. and van den Bosch F.(2008). The Study of Plant Disease Epidemics, 421 pp. APS Press, St Paul, MN, USA.

Milne, A., Pavley, N., Audsley, E. and Parsons, D. (2007). A model of effect of fungicides on disease induced yield loss for use in wheat disease management decision support system. Ann. Appl. Biol.151:113-125.

Pannu, P.P.S. Mohan C., Gitanjali, Singh G., Kaur J., Mann, Bala S.K., Prashar, M., Bhardwaj, S.C., Meeta, M., Sharma I. and Rewal, H.S. (2010).Occurrence of yellow rust of wheat, its impact on yield viz-a-viz its management. $P l$. Dis. Res. 25 (2):144-150

Peterson, R. F., Campbell, A.B. and Hannah A.E. (1948). A diagrammatic scale for estimating rust intensity of leaves and stems of cereals. Canadian J. Res., Sect. C 26, 496500 .

Sharp, E.L. (1965), Prepenetration and postpenetration environment and development of Puccinia striiformis. Phytopathl., 55.198-203.

Bregaglio, S., Donatelli M. and Confalonieri R. (2013). Fungal infections of rice. wheat. and grape in Eurove in 2030 2050. Agron. Sustain. Dev 33:767-776.

Singh, J. B., Pradeep Saxena, Pandey K. C. and Pradeep Behari (2010). Comparing models for temporal progress of zonate leaf spot (Gloeocercospora sorghi) disease in sorghum (Sorghum bicolor) Indian Agric. Sci. 80 (6): 527-31.

Wellings, C.R. (2011). Global status of stripe rust: a review of historical and current threats. Euphytica. 179. 129-141. 